\title{
ВЗАИМОДЕЙСТВИЕ МОНАЦИТА И БИФТОРИДА АММОНИЯ
}

\author{
Муслимова Александра Валерьевна', \\ klameriß@gmail.com
}

\author{
Буйновский Александр Сергеевич \\ ASBujnovskij@mephi.ru
}

\author{
Молоков Петр Борисович', \\ PBMolokov@mephi.ru
}

\section{Софронов Владимир Леонидович', VLSofronov@mephi.ru}

' Северский технологический институт - филиал Национального исследовательского ядерного университета «МИФИ», Россия, 636036, г. Северск, пр. Коммунистический, 65.

\begin{abstract}
Новейшие технологии, которые обеспечивают научно-технический прогресс, опираются на уникальные свойства редкоземельных металлов и их соединений. В последние годы предприняты попытки по возрождению производства редкоземельных металлов в России, в основном за счет источников, из которых редкоземельные элементы можно извлекать попутно (апатитов, фосфоритов и продуктов их переработки). Еще один источник редкоземельных элементов, представляющий собой готовый концентрат, - монацитовый концентрат, хранящийся на складе государственного казенного учреждения Свердловской области «УралМонацит» в г. Красноуфимске. Известные промышленные технологии (щелочная и сернокислотная) переработки монацита имеют ряд недостатков, в частности неполноту выделения редкоземельных элементов и сложность отделения тория от редкоземельных элементов, поэтому работы по совершенствованию технологий переработки монацитового сырья с извлечением из него концентрата редкоземельных элементов с очисткой от примесей, в том числе тория, являются актуальными. Для эффективного разложения трудновскрываемой кристаллической решетки монацита предложено его фторирование при помощи гидрофторида аммония, как относительно экологичного и регенерируемого реагента.
\end{abstract}

Цель: исследовать процесс и установить особенности взаимодействия монацитового концентрата с бифторидом аммония с получением продукта, пригодного для дальнейшей сернокислотной переработки.

Объект: образец партии монацитового концентрата базы хранения ГКУ СО «УралМонацит».

Методы: атомно-эмиссионная спектроскопия с индуктивно-связанной плазмой, рентгенофлуоресцентный анализ, нейтронноактивационный анализ, рентгенофазовый анализ, сканирующая электронная микроскопия с микроанализом, метод совмещенного термогравиметрического/дифференциально-термогравиметрического/дифференциально-сканирующего калориметрического анализа.

Результаты. Рассмотрена первая стадия предложенной фтораммонийно-сернокислотной переработки монацитовых концентратов - стадия гидрофторирования. При взаимодействии монацитового концентрата с бифторидом аммония в первую очередь в реакцию вступают примеси, содержащиеся в концентрате, образуя соответствующие фториды и фтораммонийные соединения, и лишь потом фосфаты редкоземельных металлов. Выделяющаяся при этом фосфорная кислота взаимодействует с бифторидом аммония с образованием гидрофосфатов аммония и незначительным выделением фосфора в газообразную фазу. Это подтверждается результатами исследований, проведенных в интервале температур 170-250 ㄷ: 49,2-83,3 \% фосфора при фторировании остается в твердой фазе, в жидкую переходит 12,0-32,8 \%, в газообразную - от 11,2 до 28,1\%. На полученных ТГАи ДСК-кривых при дальнейшем увеличении температуры вплоть до $500^{\circ} \mathrm{C}$ отсутствуют признаки протекания реакций, что позволяет говорить о том, что полная отгонка фосфора из продуктов фторирования в изученном интервале температур невозможна. По материальному балансу 10,4-38,4 \% кремния переходит в газовую фазу в виде SiF 4 , 55,3-75,9 \% - в раствор выщелачивания в виде растворимого $\left(\mathrm{NH}_{4}\right)_{2} \mathrm{SiF}_{6}$, который может быть разложен до газообразного SiF ке. На основании полученных результатов выбраны оптимальные условия для проведения процесса фторирования монацитового концентрата гидрофторидом аммония: температура $210{ }^{\circ} \mathrm{C}$; содержание бифторида аммония $80 \%$ от стехиометрии; продолжительность процесса 1,5 часа.

\section{Ключевые слова}

Монацит, монацитовый концентрат, гидродифторид аммония, бифторид аммония, редкоземельные элементы, торий, кремний, фосфор.

\section{Введение}

Монацит - минерал, являющийся ценным источником редкоземельных элементов (РЗЭ) и тория. Промышленно освоенными методами его переработки являются сернокислотный и щелочной. Большое количество публикаций посвящено усовершенствованию сернокислотной [1-3] или щелочной технологий переработки монацита $[4,5]$, также в литературе рассматривается применимость таких методов, как бактериологическое вы- щелачивание [6], сульфатизация и пирогидролиз до $800{ }^{\circ} \mathrm{C}$ [7], автоклавное азотнокислотное выщелачивание $[8,9]$, сверхкритическая флюидная экстракция [10] и других.

В г. Красноуфимске на Урале (Свердловская обл.) хранится около 80 тысяч тонн монацита из 800 различных партий. Наиболее обширные исследования состава различных партий этого монацитового концентрата (МК) приведены в работах $[11,12]$ на примере 34 партий. Содержание мона- 
цита в концентратах оценено от 78 до $100 \%$, авторами также предложена предварительная классификация этих материалов: на основании данных об их химическом составе, по окраске, степени прозрачности, форме зерен [12].

Для монацита в целом характерна высокая взаимная растворимость и широкий изоморфизм с хаттонитом $\left(\mathrm{ThSiO}_{4}\right)$ [13]. Из этого можно сделать вывод о вероятной нецелесообразности применения основных промышленных методов переработки монацита. При щелочной переработке из-за невысокого и непостоянного качества МК увеличивается расход достаточно дорогого вскрывающего агента на разложение балластных примесей. Присутствие в части партий МК вростков минераловсиликатов повлечет снижение степени извлечения РЗЭ при кислотной переработке.

Основной метод удаления кремния из силикатных или кремнийсодержащих матриц минералов заключается во фторировании таких материалов с удалением кремния в виде летучего $\mathrm{SiF}_{4}$, что часто используется в пробоподготовке в совокупности с эффективным разрушением кристаллической решетки трудноразлагаемых материалов под действием фторирующих агентов [14, 15]. В случае фторирования монацита образуются фториды РЗЭ, тория, примесей, что усложняет процесс очистки и разделения полученных соединений из-за низкой растворимости фторидов РЗЭ и тория по сравнению с другими схемами переработки.

Известен метод отгонки фторидов из растворов нелетучих кислот, в частности $\mathrm{H}_{2} \mathrm{SO}_{4}$, который хорошо зарекомендовал себя в пробоподготовке для разложения трудновскрываемых проб горных пород, силикатов, а также других проб, содержащих кремний или кремниевую кислоту, для разрушения прочных фторидных комплексов металлов [16]. Предположительно, применение фторирования при переработке монацита в случае эффективной конверсии полученных фторидов редкоземельных металлов (РЗМ) в сульфаты позволит увеличить выход РЗЭ по сравнению с классической сернокислотоной переработкой.

Данный метод был рассмотрен в работах [17-19]: предложено проводить фторирование монацита в смеси фторида аммония и серной кислоты при $260{ }^{\circ} \mathrm{C}$, а затем при $340{ }^{\circ} \mathrm{C}$ производить отгонку фтора из образовавшихся фторидов с переводом их в сульфатные соединения. При этом в источниках приведены противоречивые сведения о поведении фосфора в процессе фторирования фосфатных минералов фтораммонийными соединениями: в работе [19] указано, что при нагреве смеси монацита, фторида аммония и серной кислоты до $340{ }^{\circ} \mathrm{C}$ значительная часть фосфора переходит в газообразную фазу в виде $\mathrm{PF}_{5}$; а в работе [20] при термогравиметрическом исследовании взаимодействия бифторида аммония (БФА) и апатита авторами было обнаружено, что при $320^{\circ} \mathrm{C}$ в газовую фазу выделяется лишь около $10 \%$ фосфора в виде $\mathrm{POF}_{3}$, при дальнейшем нагреве до $800{ }^{\circ} \mathrm{C}$ это значение не пре- вышает $65 \%$. Поведение фосфора в процессе переработки МК имеет важное значение, так как его содержание в концентратах в среднем оценивается в 22,2 мас. \% (на $\left.\mathrm{P}_{2} \mathrm{O}_{5}\right)$ [11], и в связи с этим велико влияние на технологический процесс выделения РЗЭ.

Возможность отделения от РЗЭ при фторировании монацита ряда примесей, в частности кремния и фосфора, значительно упрощает дальнейшую переработку растворов выщелачивания сульфатов. Предложенные в работах [17-19] условия и стадийность фтораммонийно-сернокислотной переработки имеют ряд недостатков: состав газовой фазы усложняет ее очистку и выделение БФА для рециклинга, увеличивается расход фторида аммония на реакцию с серной кислотой, из-за необходимости применения избытка реагентов продукты образуют спеки, что повышает продолжительность процесса удаления летучих продуктов разложения и осложняет стадию следующего выщелачивания ценных компонентов.

Для устранения указанных недостатков было предложено разделить стадии фторирования МК БФА и сульфатизации получаемого продукта. В связи с этим были проведены исследования по изучению вещественного и химического состава исходного сырья, установлению его особенностей, а также исследование процесса взаимодействия МК с БФА с целью получения продукта, пригодного для дальнейшей кислотной переработки.

\section{Методика анализа объекта исследований}

Для проведения исследований были отобраны две технологические пробы (проба I и проба II), различающиеся по внешнему виду (цвету), от партий монацитового концентрата со складов ГКУ СО «УралМонацит».

Исходный МК подвергли ситовому анализу при помощи аналитической просеивающей машины AS 200 («RETSCH GmbH», Германия) методом сухого рассева. Масса исходной навески для рассева 500 г.

Предварительную оценку химического состава МК проводили методом РФА при помощи волнодисперсионного спектрометра «Спекроскан МАКСGVM». В качестве образцов сравнения использовали таблетки, полученные прессованием порошка из смеси точно отобранных навесок оксидов определяемых элементов (ос.ч.) с содержанием по основному веществу не менее 99,0 мас. \% . Количественную оценку химического состава МК проводили методами нейтронно-активационного анализа (НАА) (ЯР ТПУ, г. Томск) и атомно-эмиссионной спектроскопии (АЭС) на приборе іСАР-6200. Растворение проб для АЭС проводили с использованием микроволновой системы MARS 6. Для построения градуировочных графиков использовали аттестованные многоэлементные стандартные растворы МЭС-1, МЭС-2, МЭС-3, МЭС-4 и МЭС-РЗЭ (000 «НПП Скат», г. Новосибирск), а также растворы нитратов тория и урана ([Th] $=0,5$ г/дм 
$[\mathrm{U}]=0,5$ г/дм³ $)$. В качестве внутреннего стандарта использовали азотнокислотный раствор кадмия.

Шлифы зерен МК исследованы методом сканирующей электронной микроскопии (СЭМ) на приборе «Hitachi S-3400N» (ТПУ, г. Томск), получены карты распределения ряда элементов по поверхности шлифа и энергодисперсионные спектры в точках.

Рентгенофазовый анализ проводили на дифрактометре ДРОН-3 с идентификацией фаз по картотеке JCPDS. Параметры съемки: длина волны характеристического излучения $\lambda(\mathrm{CuK} \alpha)=0,154 \mathrm{Hм}$; экспозиция 0,5 с; диапазон измерения углов дифракции $(2 \theta)$ - 10-98 град; скорость изменения углов $2 \theta$ в процессе съёмки - 0,5 град/мин.

\section{Характеристика объекта исследования}

По результатам определения гранулометрического состава концентрата получили, что основная фракция $(49,2 \%)$ относится к классу крупности $(+0,16) . . .(-0,315)$ мм, суммарно $79,8 \%-$ к классу крупности $(+0,16) . . .(-0,5)$ мм. Выход во фракцию $(-0,1)$ мм составил $0,9 \%$, во фракцию $(+1)$ мм $0,6 \%$; выход концентрата по другим фракциям, а также интегральный выход представлены на рис. 1.

Результаты исследований химического состава МК представлены графически на рис. 2. Содержание оксидов РЗЭ варьируется от 41,00 до 43,89 мас. \%, $\mathrm{P}_{2} \mathrm{O}_{5}-19,92-20,67$ мac. $\%, \mathrm{SiO}_{2}-3,14-3,36$ мac. $\%$, $\mathrm{ThO}_{2}-5,88-6,11$ мac. $\%, \mathrm{U}_{3} \mathrm{O}_{8}$ 0,16-0,28 мас. \%. Химический состав проб I и II близок, расхождения в содержании железа, титана и ниобия связаны, судя по всему, с разным составом примесных минералов в пробах концентрата. Расхождения между результатами АЭС и НАА заметны для некоторых оксидов РЗЭ $\left(\mathrm{Pr}_{2} \mathrm{O}_{3}, \mathrm{Sm}_{2} \mathrm{O}_{3}, \mathrm{~Tb}_{2} \mathrm{O}_{3}\right)$ и, вероятно, связаны с влияниями на аналитические линии присутствия в пробе урана и железа.

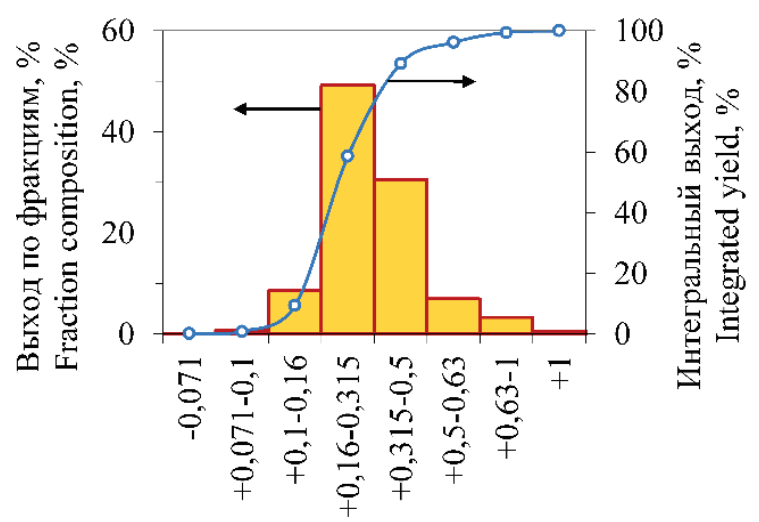

Класс крупности, мм / Fraction, mm

Рис. 1. Выход по фракииял и интегральная кривая гранулометрического состава исследуемого образиа $M K$

Fig. 1. Fraction composition and integral curve of the granulometric composition of the monazite concentrate sample

Исследование участка зерна МК с использованием СЭМ (рис. 3) показало, что пространственное распределение основных компонентов МК по поверхности относительно равномерное. Это позволяет достаточно уверенно говорить о том, что торий, уран и продукт их распада Рb входят в кристаллическую решетку монацита и находятся в изоморфной форме. В то же время в ряде участков наблюдается неоднородность в распределении Th, $\mathrm{Si}, \mathrm{Ca}$ (рис. 3, б-г). Это позволяет предположить присутствие в зернах монацита хаттонита и чералита (Th, $\mathrm{Ca}, \mathrm{Ce})\left(\mathrm{PO}_{4}, \mathrm{SiO}_{4}\right)$, что является характерной особенностью монацита вследствие широкого изоморфизма с указанными минералами. Спектр, снятый с участка с однородным распределением исследованных элементов (рис. 4, спектр 1), в целом соответствует типичному спек-
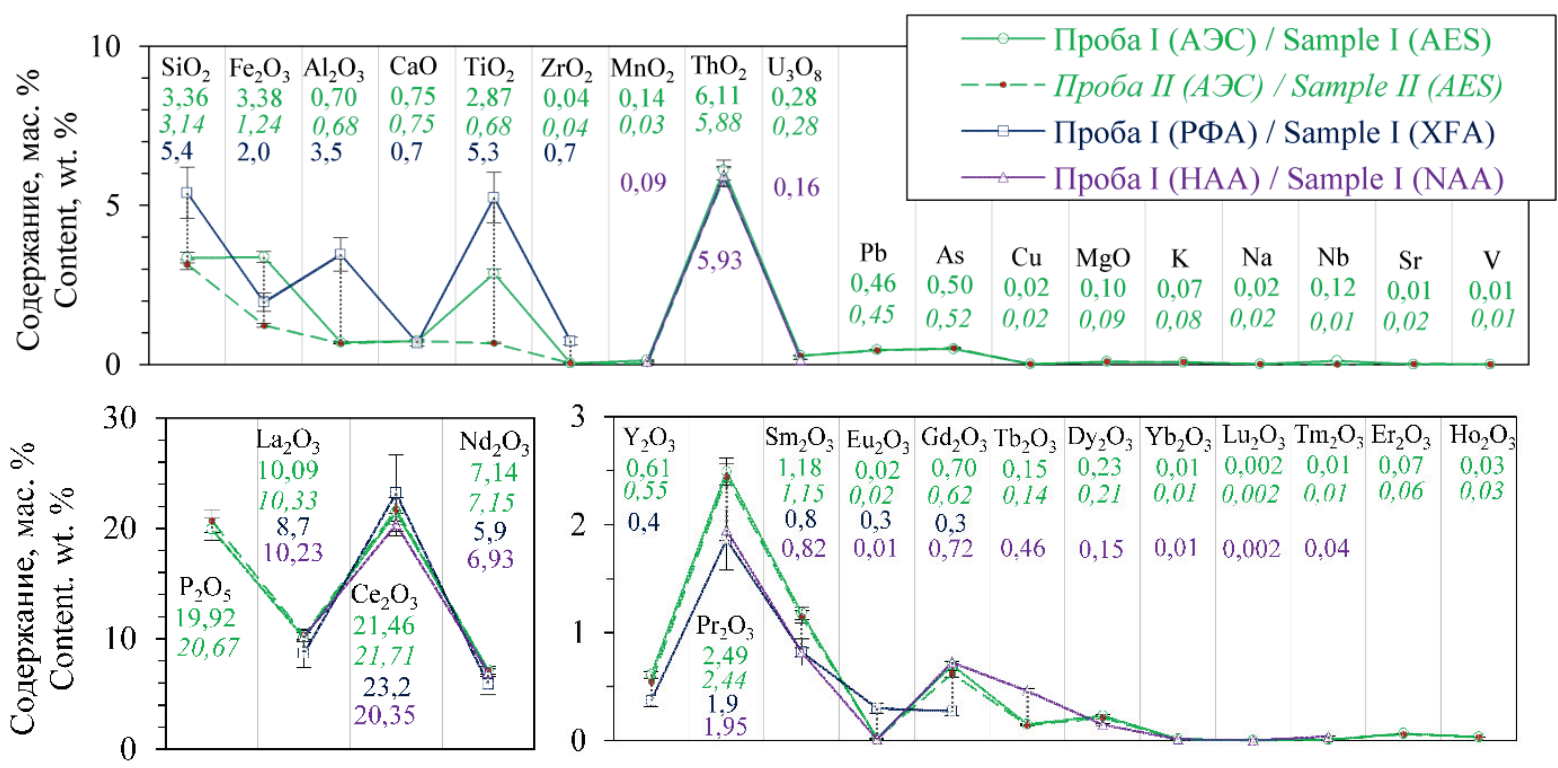

Pис. 2. Результаты хилического анализа МК (в легенде в скобках рядол с нолером пробы указан метод анализа, также введены иветовые обозначения, соответствующие иифровым данным, нанесенным на графики)

Fig. 2. Results of chemical analysis of monazite concentrate (in the legend, the method of analysis is indicated in parentheses next to the sample number, color symbols are also introduced corresponding to the digital data plotted on the graphs) 


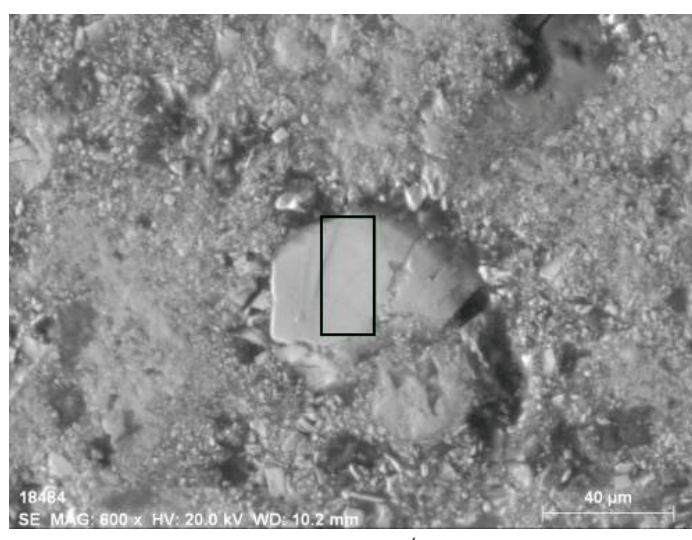

$a / a$

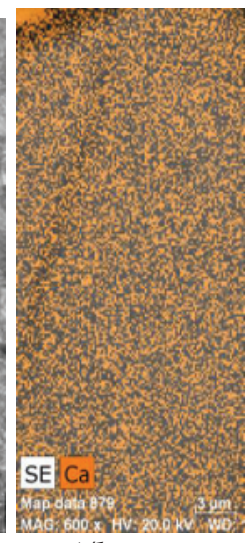

$\sigma / b$

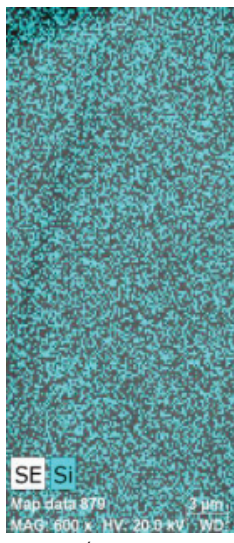

$B / c$

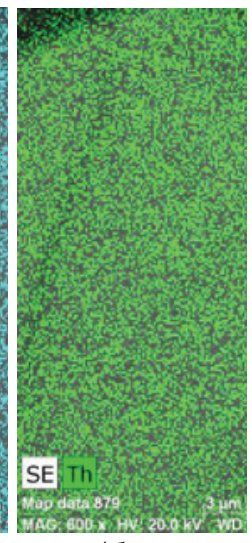

$2 / d$

Puс. 3. Распределение кальция, кремния и тория на выделенном участке зерна монацита: а) SE-изображение исходного зерна с указаниел области сканирования; б) распределение по области сканирования кальция, в) кремния, г) тория

Fig. 3. Distribution of calcium, silicon and thorium on the isolated area of monazite grain: a) SE-image of the initial grain with indication of the scanning area; $b$ ) distribution along the scanning area of calcium, $c$ ) silicon, $d$ ) thorium

тру монацита. В спектре, снятом с участка с неоднородным распределением элементов (рис. 4, спектр 2), обнаружены большие содержания кальция, кремния, железа.

По результатам исследований фазового состава данной пробы определено присутствие основных компонентов монацита - фосфатов РЗЭ моноклинной сингонии (церия и лантана, карточки JCPDS № 32-199 и № 35-731), а также ортосиликата тория моноклинной сингонии (№ 4-613) и диортосиликата неодима с орторомбической кристаллической решеткой (№ 26-1276). Это подтверждает присутствие в образце монацита вростков хаттонита, а также показывает, что с силикатной фазой также связана часть РЗЭ, в частности неодим. Таким образом, на основании классификации, предложенной в [2], исследуемую пробу МК можно отнести к типу Монацит-1, для которого характерны вростки хаттонита и чералита.

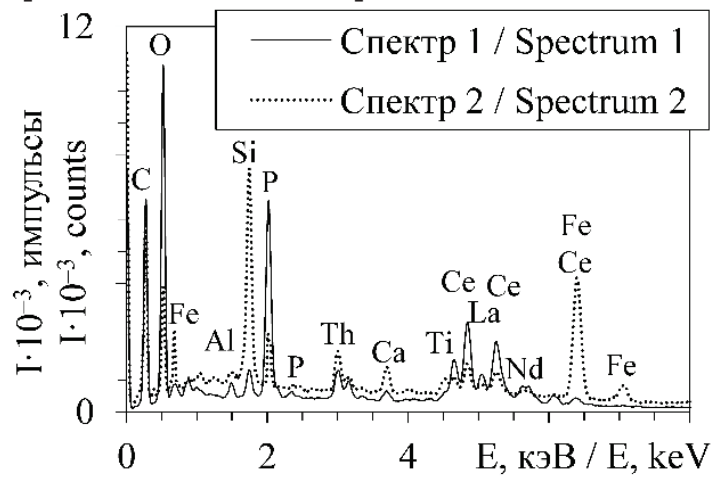

Puc.4. Спектры, снятые с областей однородного (спектр 1) и неоднородного (спектр 2) распределения элементов по зерну монацита

Fig. 4. Spectra taken from regions of homogeneous (spectrum 1) and inhomogeneous (spectrum 2) distribution of elements along the grain of monazite

Следует отметить, что при кислотной переработке концентратов, содержащих кремний, воз- можно образование гелей и коллоидов кремнекислоты, что может значительно осложнять стадии фильтрации или центрифугирования. Тесное врастание хаттонита в монацит и связывание части РЗЭ в силикаты при кислотной переработке приведет к снижению выхода РЗЭ, поэтому для удаления из концентрата кремния, а также разрушения матрицы самого монацита перед кислотной переработкой провели исследования по взаимодействию БФА с МК.

\section{Методика экспериментальных исследований}

Гидрофторирование проводили, помещая в стеклоуглеродный тигель объемом $50 \mathrm{~cm}^{3}$ навески измельченного БФА (ч.) и МК исходной крупности и перемешивая. Тигель выдерживали заданное время в муфельной печи, заранее нагретой до температуры эксперимента. Провели три серии экспериментов:

- продолжительность процесса $\tau=(1,0 ; 1,5 ; 2,0 ; 2,5)$ часов при количестве БФА от стехиометрически необходимого $v=110 \%$ и температуре $t=230^{\circ} \mathrm{C}$;

- $v=(80,90,100,110,120) \%$ при $t=230{ }^{\circ} \mathrm{C}$ и $\tau=2,5$ часа;

- $t=(170,190,210,230,250){ }^{\circ} \mathrm{C}$ при $\tau=2,5$ часа и $v=110 \%$ от стехиометрического.

Расчет стехиометрически необходимого количества БФА вели, полагая, что при фторировании фосфатов РЗЭ, тория и иттрия образуются соответствующие фториды, фосфорная кислота, фтороводород и аммиак, а при фторировании оксидов примесей - фториды кальция, магния, урана и фтораммонийные соединения железа, алюминия, кремния, титана, циркония, а также аммиак и вода. Таким образом на 1,0 г МК необходимо взять 1,0 г БФА.

K полученному продукту фторирования добавляли дистиллированную воду в расчете 1 г исходного концентрата: $10 \mathrm{~cm}^{3}$ воды и проводили выще- 
лачивание в течение 30 минут при перемешивании и нагреве до $50{ }^{\circ} \mathrm{C}$ для удаления непрореагировавшего БФА и растворимых продуктов фторирования. После фильтрации раствор анализировали методом АЭС по методике, описанной ранее. Степени извлечения элементов $(\alpha)$ рассчитывали как отношение массы элемента, перешедшего в раствор, к массе элемента в исходном MК, выраженное в процентах.

Высушенные и истертые до прохождения через сито с размером ячейки 0,1 мм образцы нерастворенных остатков (н.о.) прессовали в таблетки с подложкой из борной кислоты при помощи пресса ПЛГ-20 при усилии 7 тонн и проводили РФА, используя метод фундаментальных параметров, при помощи волнодисперсионного спектрометра «Спекроскан MAKC-GVM» и энергодисперсионной приставки Oxford Instruments INCA X-Act для определения содержания фтора. В качестве эталонов были использованы смеси монацита известного состава проб I и II, определенного методом АЭС, с фторидом натрия и фторидом неодима. Расхождения в содержании элементов, образующих нерастворимые соединения (Ca, La), с расчетным содержанием не превышали 10 отн. \%. Термогравиметрическое взаимодействие МК и БФА проводили на приборе SDT Q600 при условиях: масса навески 10,0 мг, нагрев до $650{ }^{\circ} \mathrm{C}$ со скоростью $5^{\circ} /$ мин в атмосфере аргона, материал тигля $\mathrm{Al}_{2} \mathrm{O}_{3}$. Шихту готовили истиранием смеси в агатовой ступке при массовом соотношении МК: БФА=1:1. Рентгенофазовый анализ образца продукта гидрофторирования МК проводили на дифрактометре ARL X'TRA, идентификацию фаз по базе данных ICDD PDF-2. Параметры съемки: $\lambda(\mathrm{CuK} \alpha)=0,1518$ нм; $2 \theta=10-60^{\circ} ;$ экспозиция 2,4 с; скорость изменения углов $2 \theta$ в процессе съёмки - 0,3 \%мин. Поверхность частиц порошка продукта гидрофторирования МК исследовали методом СЭМ на приборе Vega 3 SBH (Tescan). Для получения карт распределения использовали вышеуказанную приставку X-Act.

\section{Результаты}

На рис. 5, а, приведены ТГ- и ДТГ-кривые, на рис. 5, б, - ДСК-кривая процесса взаимодействия МК и БФА.

Компоненты шихты начинают вступать во взаимодействие уже при комнатной температуре при истирании, что видно по потере массы при $30{ }^{\circ} \mathrm{C}$ на ДТГ-кривой. Взаимодействие минераловпримесей концентрата с БФА начинается при $50{ }^{\circ} \mathrm{C}$, то есть еще до его расплавления (эндоэффект при $\left.121{ }^{\circ} \mathrm{C}\right)$, и достигает максимальной скорости при $176{ }^{\circ} \mathrm{C}$. При этом образуются двойные соли железа, алюминия, титана, кремния (например, $\left(\mathrm{NH}_{4}\right)_{3} \mathrm{FeF}_{6} \cdot \mathrm{nNH}_{4} \mathrm{~F}$ [21]). На этот процесс налагается процесс разложения БФА с максимумом при $186{ }^{\circ} \mathrm{C}$. Процесс с максимумом при $203^{\circ} \mathrm{C}$, видимо, отвечает разложению образованных ранее двойных солей.

Максимум на ДТГ-кривой при $217{ }^{\circ} \mathrm{C}$ соответствует взаимодействию монацита и БФА с выделением фосфорной кислоты, при $257^{\circ} \mathrm{C}$ - взаимодействию фосфорной кислоты с БФА с образованием $\mathrm{NH}_{4} \mathrm{HPO}_{3} \mathrm{~F}$ по предположенным реакциям [20]:

$$
\mathrm{H}_{3} \mathrm{PO}_{4}+2 \mathrm{NH}_{4} \mathrm{HF}_{2}=\mathrm{NH}_{4} \mathrm{PO}_{2} \mathrm{~F}_{2}+\mathrm{NH}_{3} \uparrow+2 \mathrm{HF} \uparrow+2 \mathrm{H}_{2} \mathrm{O} \text {, }
$$$$
2 \mathrm{NH}_{4} \mathrm{PO}_{2} \mathrm{~F}_{2}=\mathrm{NH}_{4} \mathrm{HPO}_{3} \mathrm{~F}+\mathrm{POF}_{3} \uparrow+\mathrm{NH}_{3} \uparrow \text {. }
$$

При температуре $549{ }^{\circ} \mathrm{C}$, по-видимому, по аналогии с предложенной стадийностью в работе [20], происходит взаимодействие образованных фторидов металлов с гидромонофторфосфатом аммония с образованием фторфосфатов. Связывание фосфора в нерастворимые соединения при нагреве пробы до $600{ }^{\circ} \mathrm{C}$ подтверждается тем, что при выщелачивании спека после ТГ-анализа степень извлечения фосфора в раствор составила лишь 2,3 \% относительно его содержания в исходном МК. Следует отметить, что при термогравиметрических исследованиях положения максимумов зависят от выбранной скорости нагрева и могут быть использованы для оценки стадийности процесса, но не могут быть перенесены на исследования взаимодей-
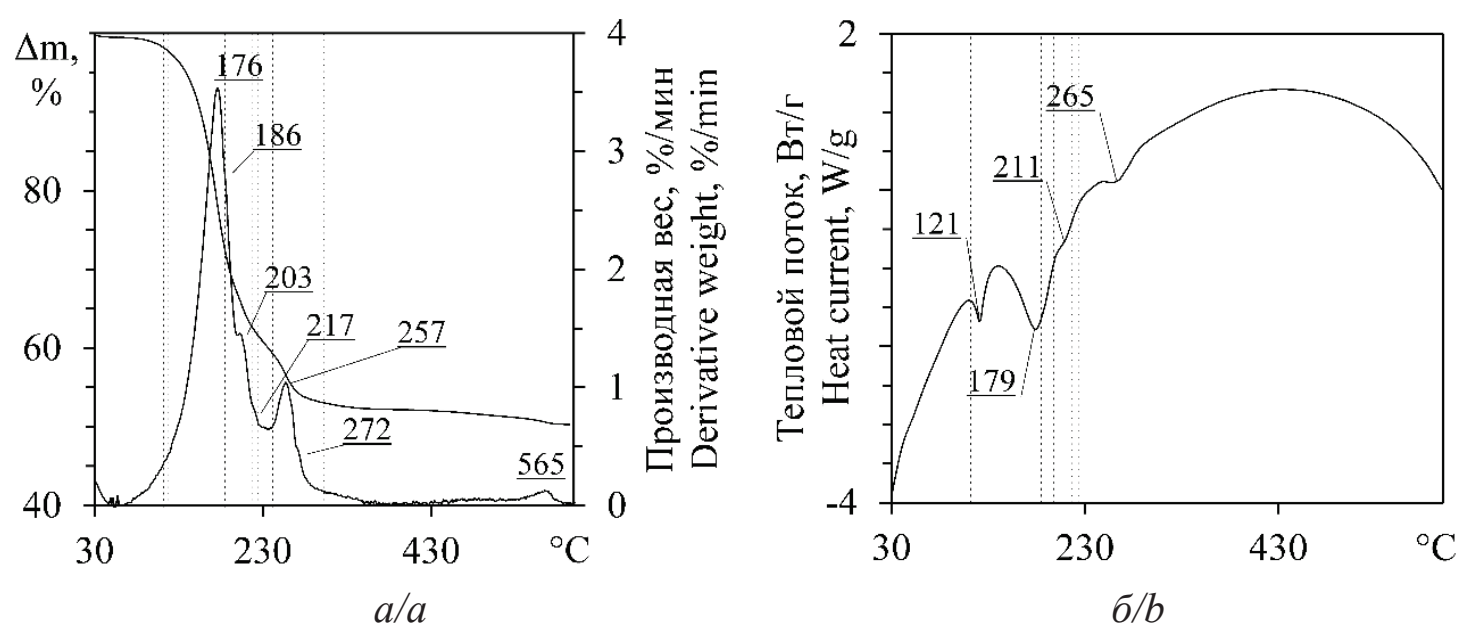

Pис. 5. ТГ-, ДТГ- (а), ДСК-кривые (б) взаимодействия монацитового концентрата с БФА

Fig. 5. TG-, DTG- (a), DSC-curves (b) of monazite concentrate interaction with ammonium bifluoride 

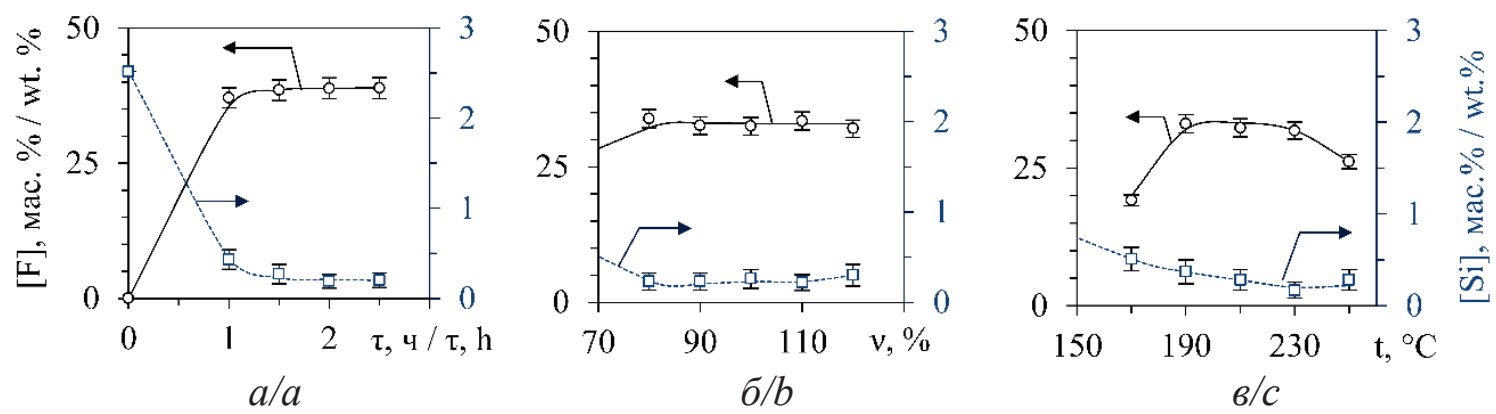

Pис. 6. Графики зависимости содержания фтора и кремния в продуктах фторирования после их выщелачивания при: а) различной продолжительности процесса, б) разном количестве БФА от стехиометрически необходимого, в) различной температуре

Fig. 6. Graphs of dependence of fluorine and silicon content in fluorination products after leaching at different: a) process duration, b) amounts of ammonium bifluoride from stoichiometrically necessary, $c$ ) temperatures

ствий при изотермических условиях, когда происходит наложение процессов друг на друга. В связи с этим для определения оптимальной температуры фторирования МК БФА проведены исследования в изотермических условиях.

На рис. 6 показаны результаты исследования влияния ряда факторов на содержание в продуктах фторирования фтора и кремния. Наибольшее содержание фтора в продуктах фторирования МК БФА получено в экспериментах с разной продолжительностью процесса (рис. $6, a$ ): увеличение продолжительности фторирования более $1,0-1,5$ ч практически не влияет на содержание фтора в продуктах фторирования. Также мало влияние количества БФА, использованного для фторирования, в интервале (80-120) \% от стехиометрически необходимого (рис. 6 , б). С увеличением температуры процесса с 170 до $190{ }^{\circ} \mathrm{C}$ (рис. 6, в) происходит увеличение содержания фтора в продуктах фторирования $\mathrm{MK}$, в интервале температур $190-230{ }^{\circ} \mathrm{C}$ содержание фтора практически не изменяется, дальнейшее увеличение температуры до $250{ }^{\circ} \mathrm{C}$ приводит к снижению содержание фтора в продукте. Таким образом, можно предположить, что температура $170{ }^{\circ} \mathrm{C}$ является недостаточной для интенсификации процесса, а при температурах выше $230{ }^{\circ} \mathrm{C}$ происходит частичное разложение БФА.

Также видно, что во всех экспериментах наблюдалось снижение содержания в продуктах фторирования кремния (до $0,17-0,51$ мас. \%, рис. 6 ) по сравнению с его содержанием в исходном концентрате. Содержание кремния в твердой фазе уменьшается с увеличением температуры, достигая минимальных значений при $210-230{ }^{\circ} \mathrm{C}$, и далее изменяется незначительно. При увеличении продолжительности процесса фторирования с 1,5 до 2,0 часов при $230{ }^{\circ} \mathrm{C}$ происходит снижение содержания кремния с 0,28 до 0,20 мас. \%, до 2,5 часов - содержание кремния остается практически неизменным. В связи незначительными изменениями содержания фтора и кремния в продуктах фторирования после 1,5 часов данная продолжительность процесса выбрана в качестве оптимальной.
Также незначительное влияние на содержание кремния в продуктах фторирования оказывает разное количества БФА, что связано с тем, что кремнийсодержащие соединения реагируют с БФА в первую очередь. При фторировании кремнийсодержащей части концентрата образуется хорошо растворимый фторсиликат аммония:

$$
\begin{gathered}
\mathrm{SiO}_{2}+3 \mathrm{NH}_{4} \mathrm{HF}_{2} \rightarrow\left(\mathrm{NH}_{4}\right)_{2} \mathrm{SiF}_{6}+\mathrm{NH}_{3} \uparrow+2 \mathrm{H}_{2} \mathrm{O}, \\
\mathrm{ThSiO}_{4}+5 \mathrm{NH}_{4} \mathrm{HF}_{2} \rightarrow\left(\mathrm{NH}_{4}\right)_{2} \mathrm{SiF}_{6}+\mathrm{ThF}_{4}+3 \mathrm{NH}_{3} \uparrow+4 \mathrm{H}_{2} \mathrm{O},(1) \\
\mathrm{Nd}_{2} \mathrm{Si}_{2} \mathrm{O}_{7}+9 \mathrm{NH}_{4} \mathrm{HF}_{2} \rightarrow \\
\rightarrow 2\left(\mathrm{NH}_{4}\right)_{2} \mathrm{SiF}_{6}+2 \mathrm{NdF}_{3}+5 \mathrm{NH}_{3} \uparrow+7 \mathrm{H}_{2} \mathrm{O},
\end{gathered}
$$

который возгоняется в газообразную фазу при температурах более $300{ }^{\circ} \mathrm{C}$. Поэтому в растворах выщелачивания продуктов фторирования МК определяли содержание кремния и ряда элементов, образующих при фторировании растворимые соединения. Влияние выбранных факторов на степени извлечения некоторых элементов приведено на рис. 7.

Из представленных на рис. $7, a$, данных видно, что в интервале температур $170-210{ }^{\circ} \mathrm{C}$ с увеличением температуры степени извлечения растворимых фтоаммонийных соединений алюминия, титана и кремния изменяются незначительно, при дальнейшем повышении температуры наблюдается понижение степеней извлечения указанных соединений, что может быть связано с разложением и потерей фторирующего агента. В связи с этим в качестве оптимальной температуры процесса выбрана температура $210{ }^{\circ} \mathrm{C}$. Для железа степень извлечения резко снижается при увеличении температуры с 170 до $210{ }^{\circ} \mathrm{C}$, что свидетельствует об образовании при $210{ }^{\circ} \mathrm{C}$ менее растворимого соединения.

Из данных, приведенных на рис. 7, б, видно, что извлечение титана, алюминия, железа и фосфора в раствор в основном мало изменяется при варьировании от 80 до 120 \% от стехиометрически необходимого количества используемого БФА. Также мало изменяются степени извлечения фосфора и железа, а степень извлечения кремния в раствор снижается при использовании избытка 

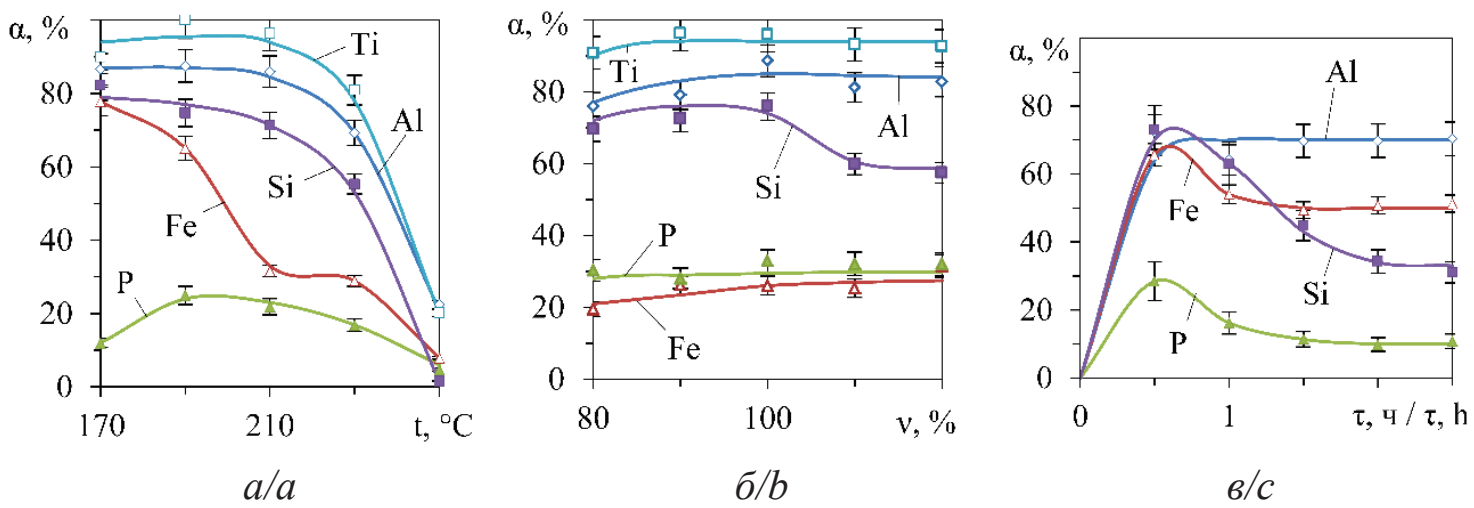

Pис. 7. Графики зависимости степеней извлечения некоторых элементов из продуктов фторирования при: а) различной температуре, б) разном количестве БФА от стехиометрически необходимого, в) различной продолжительности процесса

Fig. 7. Graphs of dependence of the extraction degrees of some elements from fluorination products at different: a) temperatures, $b$ ) amounts of ammonium bifluoride from the stoichiometrically necessary, c) process duration

БФА. При недостатке реагентов получаемые продукты после охлаждения имели порошкообразный вид либо являлись легкоизмельчаемыми спеками. С увеличением количества БФА спеки труднее поддавались измельчению, но получить легкоизмельчаемый продукт можно было, увеличив по окончании эксперимента температуру в печи до $250{ }^{\circ} \mathrm{C}$ и выдержав его в течение 1,0 часа. Целью гидрофторирования являлось не полное фторирование концентрата, а частичное разрушение кристаллической решетки монацита и выделение во фториды металлов, связанных с кремнием, перед дальнейшей сернокислотной переработкой, поэтому применение недостатка БФА предпочтительнее как с экономической точки зрения, так и с технологической: получение порошкообразного или легкоизмельчаемого материала повышает выход целевых продуктов и снижает вероятность забивки штуцеров аппарата фторирования и вывода его из строя. В качестве оптимального выбрано количество БФА, равное $80 \%$ от стехиометрически необходимого.

Степень извлечения кремния с увеличением продолжительности процесса с 0,5 до 2,5 часов уменьшается с 72,9 до $31,1 \%$, что в совокупности с данными, представленными на рис. $6, a$, происходит за счет перехода кремния в газообразную фазу в виде $\mathrm{SiF}_{4}$. Обращает на себя внимание то, что зависимости степени извлечения железа и фосфора от продолжительности процесса фторирования имеют схожий характер: при фторировании в течение $0,5-1,5$ часов они снижаются (для железа с 65,7 до 49,4 \%, для фосфора с 28,5 до 11,4 \% ), после чего изменяются незначительно. Степень извлечения алюминия практически не изменяется при увеличении продолжительности фторирования (рис. 7, в), оставаясь во всем исследованном интервале времени на уровне $70 \%$.

По полученным данным составили материальные балансы процесса фторирования по фосфору и кремнию, приведенные на рис. 8, 9. Переход в газообразную фазу определяли расчетно, по разнице между содержанием в исходном МК и содержанием в растворе выщелачивания и н.о.; при этом предполагали, что разница менее $10 \%$ связана с использованием разных методов анализа жидкой и твердой фаз, а более $10 \%$ - переходом в газообразную фазу.
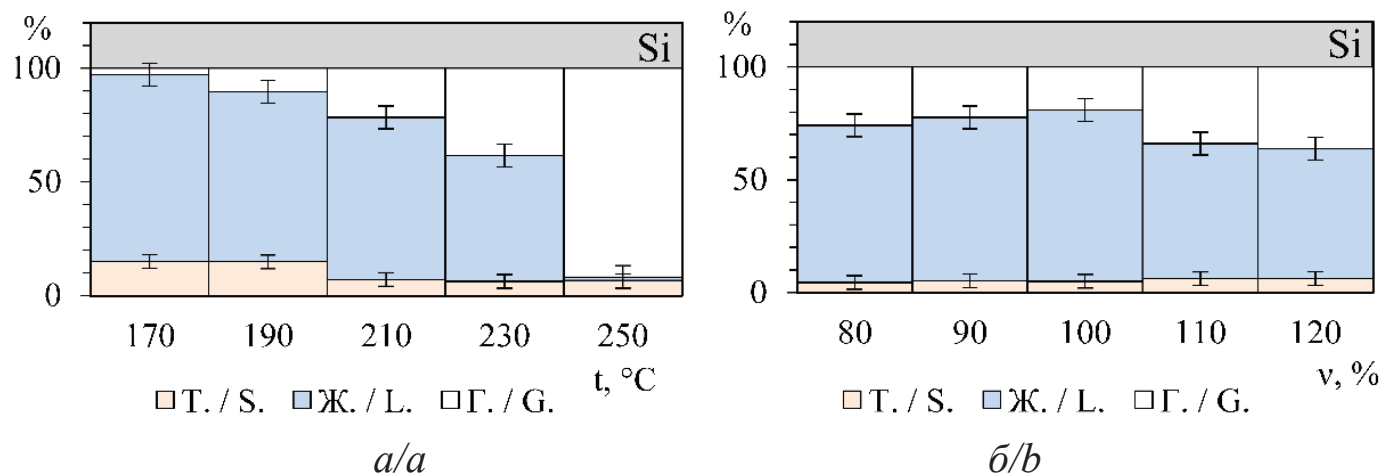

$\sigma / b$

Pис. 8. Материальный баланс процесса фторирования МК по кремнию при: а) различной телпературе, б) разнол количестве БФА от стехиометрически необходимого (Т. - обозначение твердой фазы, Ж. - жидкой, Г. - газообразной)

Fig. 8. Material balance of the monazite concentrate fluorination with respect to silicon at different: a) temperatures, $b$ ) amounts of ammonium bifluoride from stoichiometrically necessary (S. - solid, L. - liquid, G. - gaseous phase) 


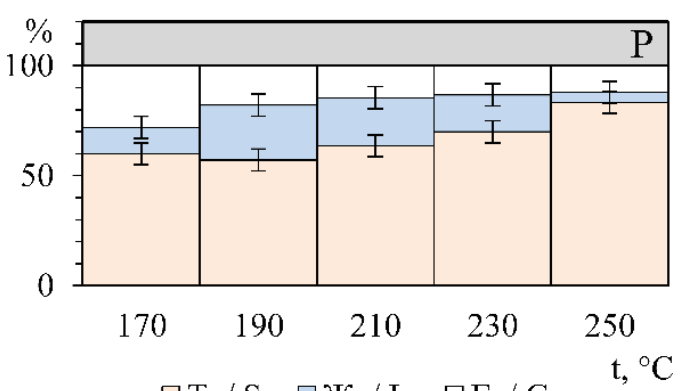

$\square$ T./S. $\square$ Ж. /L. $\square$ Г./G. $a / a$

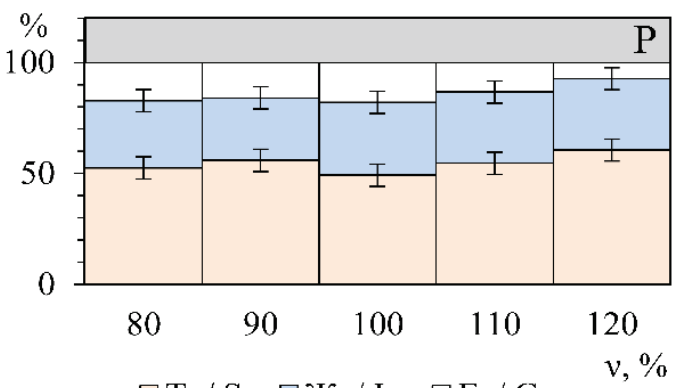

$\square$ T./S. 口Ж./L. $\square \Gamma . / \mathrm{G}$. $6 / b$

Рис.9. Материальный баланс процесса фторирования МК по фосфору при: а) различной температуре, б) разном количестве БФА от стехиометрически необходимого

Fig. 9. Material balance of the monazite concentrate fluorination by phosphorus at different: a) temperatures, $b$ ) amounts of ammonium bifluoride from stoichiometrically necessary

Материальный баланс по кремнию подтверждает сделанные ранее выводы: 10,4-38,4\% кремния (от его содержания в исходном концентрате, далее опускается) переходит в газовую фазу в виде $\mathrm{SiF}_{4}, 55,3-75,9 \%$ представлены растворимым $\left(\mathrm{NH}_{4}\right)_{2} \mathrm{SiF}_{6}$, до $14,9 \%$ остается в твердой фазе в виде исходных кремнийсодержащих минералов. Наиболее существенное отличие от указанных диапазонов наблюдается для температуры $170{ }^{\circ} \mathrm{C}$, при которой кремний распределяется между твердой и жидкой фазами в соотношении 15,0:82,2 \%, и для температуры $250{ }^{\circ} \mathrm{C}$, при которой кремний на 91,9 \% переходит в газообразную фазу. Переход кремния в газообразную фазу можно объяснить взаимодействием кремнийсодержащей части концентрата с выделяющимся при разложении БФА или при взаимодействии БФА с фосфатами РЗЭ фтороводородом:

$$
\mathrm{SiO}_{2}+4 \mathrm{HF} \rightarrow \mathrm{SiF}_{4} \uparrow+2 \mathrm{H}_{2} \mathrm{O} .
$$

Из приведенных на рис. 9 данных видно, что при фторировании часть фосфора остается в твердой фазе $(49,2-83,3 \%)$, в жидкую переходит $12,0-32,8 \%$, в газообразную - $11,2-28,1 \%$. Ранее (рис. 6,6 ) было показано, что в интервале температур $190-230{ }^{\circ} \mathrm{C}$ содержание фтора в твердых продуктах фторирования достаточно высоко, что можно связать с полнотой разрушения кристаллической решетки монацита. При этом в газовую фазу фосфор может уходить в виде $\mathrm{POF}_{3}$, в жидкую - в виде фторфосфатов аммония или фосфорных кислот, в твердой - частично оставаться в составе непрореагировавшего монацита, а частично образовывать нерастворимые фосфаты или пирофосфаты.

Для подтверждения данного предположения провели рентгенофазовый анализ для образца продукта фторирования МК, полученного при условиях: $230{ }^{\circ} \mathrm{C}, 2$ ч, $90 \%$ БФА от стехиометрически

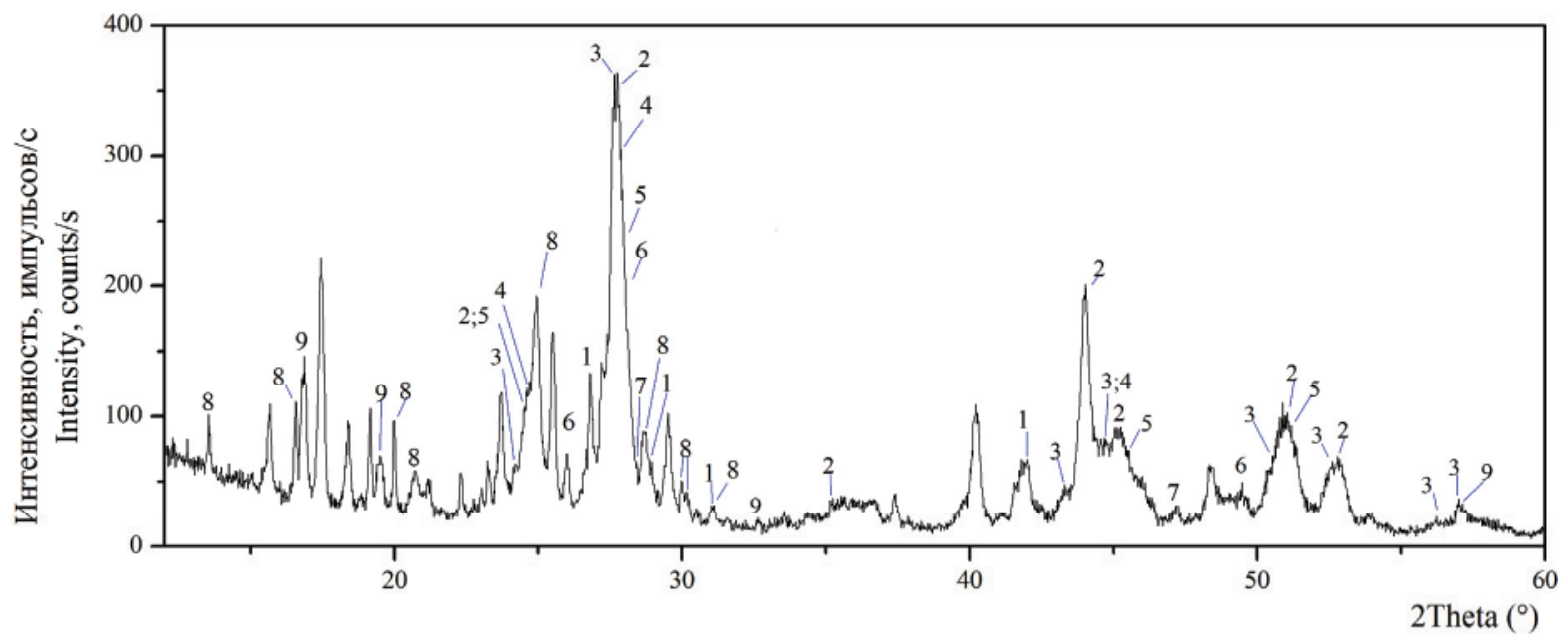

Puc. 10. Дифрактограмма продукта взаимодействия MК и БФА: 1 - монаиит, карточка PDF [029-0403]; 2-CeF [08-0045]; 3- LaF [32-0483]; $4-\mathrm{NdF}_{3}$ [09-0416]; $5-\mathrm{PrF}_{3}$ [06-0325]; $6-\mathrm{YF}_{3}$ [74-0911]; $7-\mathrm{CaF}_{2}$ [02-1302]; $8-\mathrm{ThP}_{2} \mathrm{O}_{7}$ [17-0576]; $9-$ $\left(\mathrm{NH}_{4}\right)_{3} \mathrm{FeF}_{6}[22-1040]$

Fig. 10. X-ray diffraction pattern of the product of interaction between monazite concentrate and ammonium bifluoride: 1 - monazite, PDF Card [029-0403]; 2- $\mathrm{CeF}_{3}[08-0045] ; 3-\mathrm{LaF}_{3}$ [32-0483]; 4- $\mathrm{NdF}_{3}\left[09-0416\right.$ ]; 5- $\mathrm{PrF}_{3}$ [06-0325]; 6-YF $[74-0911] ; 7-\mathrm{CaF}_{2}$ [02-1302]; 8- ThP $\mathrm{O}_{7}[17-0576] ; 9-\left(\mathrm{NH}_{4}\right)_{3} \mathrm{FeF}_{6}[22-1040]$ 
необходимого, после промывки водой. Полученная дифрактограмма представлена на рис. 10.

Из данных, представленных на рис. 10, видно, что при взаимодействии с расплавом БФА:

- фосфаты РЗЭ образуют соответствующие малорастворимые фториды:

$\mathrm{LaPO}_{4}+3 \mathrm{NH}_{4} \mathrm{HF}_{2} \rightarrow \mathrm{LaF}_{3}+\mathrm{H}_{3} \mathrm{PO}_{4}+3 \mathrm{NH}_{3} \uparrow+3 \mathrm{HF} \uparrow$.

- соединения кальция переходят во фторид кальция:

$$
\mathrm{CaO}+\mathrm{NH}_{4} \mathrm{HF}_{2} \rightarrow \mathrm{CaF}_{2}+\mathrm{NH}_{3} \uparrow+\mathrm{H}_{2} \mathrm{O} .
$$

- соединения примесных металлов образуют соответствующие фторметаллаты, что подтверждается присутствием гексафторферрата аммония в продуктах фторирования и согласуется с литературными данными [22]:

$$
\mathrm{Fe}_{2} \mathrm{O}_{3}+6 \mathrm{NH}_{4} \mathrm{HF}_{2} \rightarrow 2\left(\mathrm{NH}_{4}\right)_{3} \mathrm{FeF}_{6}+3 \mathrm{H}_{2} \mathrm{O} \text {. }
$$

Присутствие пирофосфата тория подтверждает сделанные ранее выводы о том, что образующаяся по реакции (2) фосфорная кислота при нагреве в расплаве частично переходит в пирофосфорную:

$$
2 \mathrm{H}_{3} \mathrm{PO}_{4} \rightarrow \mathrm{H}_{4} \mathrm{P}_{2} \mathrm{O}_{7}+\mathrm{H}_{2} \mathrm{O}
$$

и затем вступает во взаимодействие с компонентами расплава, в частности с фторидом тория (реакция (1)) с образованием нерастворимых пирофосфатов:

$$
\mathrm{ThF}_{4}+\mathrm{H}_{4} \mathrm{P}_{2} \mathrm{O}_{7} \rightarrow \mathrm{ThP}_{2} \mathrm{O}_{7}+4 \mathrm{HF} \uparrow,
$$

изменение энергии Гиббса данной реакции принимает отрицательные значения при температурах выше $150{ }^{\circ} \mathrm{C}$, а при $230{ }^{\circ} \mathrm{C}$ становится равным $(-33,4)$ кДж (рассчитано по данным [3] и базе данных HSC Chemistry 7.1).

Этим также можно объяснить процесс, зафиксированный на термограмме (рис. $5, a)$ при $272{ }^{\circ} \mathrm{C}$ и ранее не объясненный. Возможность образования пирофосфатов кальция при взаимодействии БФА и апатита отмечена в работе [23], но для более высоких температур - при $400{ }^{\circ} \mathrm{C}$.

При анализе продукта до промывки при помощи СЭМ (рис. 11) также обнаружена образованная в процессе гидрофторирования фаза, содержащая железо и фосфор (отмечена стрелками).

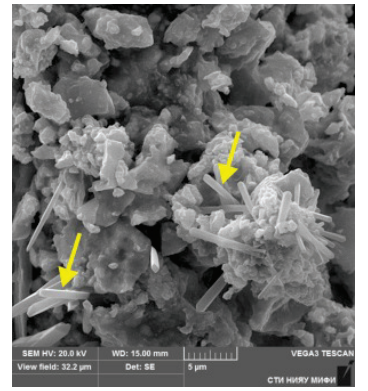

$a / a$

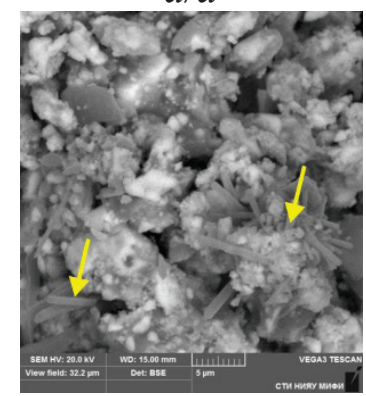

$\sigma / b$

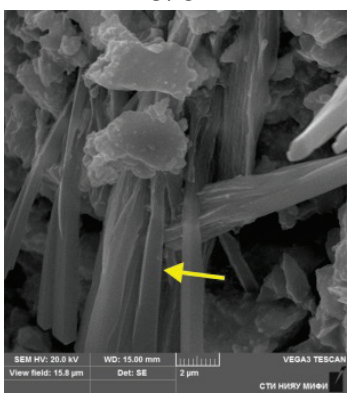

B/C
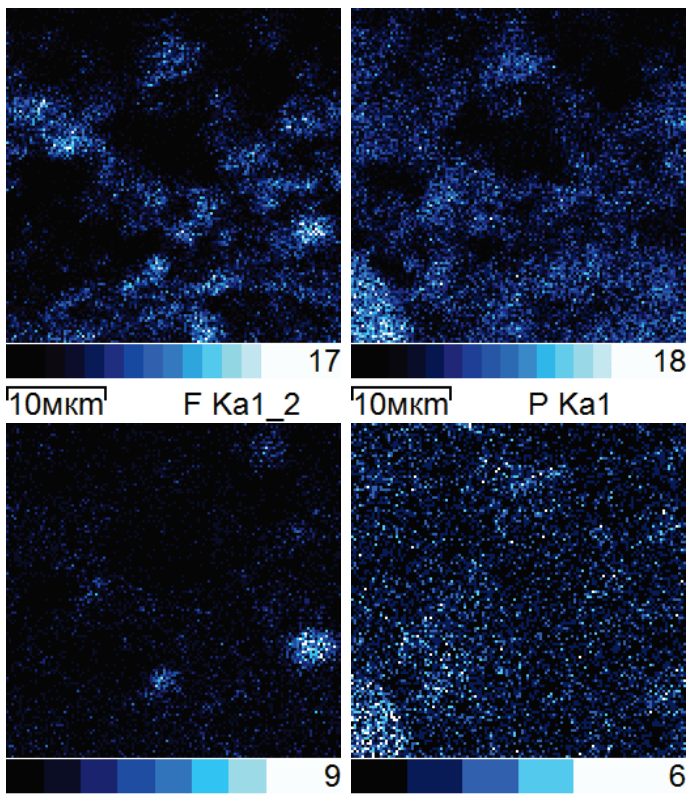

10мкm P Ka1
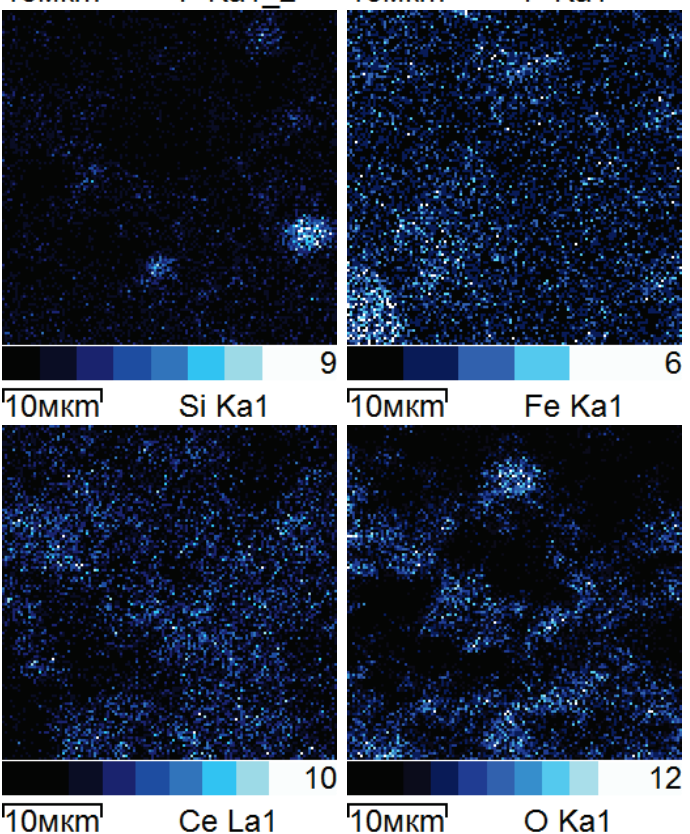

$2 / d$

Рис. 11. Изображение агломерата в продуктах фторирования (а) во вторичных и (б) в обратно отраженных электронах; в) увеличенное изображение фазы, содержащей железо и фосфор, во вторичных электронах; г) распределение ряда элементов (указаны под каждой картой) по поверхности, представленной на рис. 11, а, б

Fig. 11. Image of the agglomerate in fluorination products (a) in the secondary and $(b)$ in the backward reflected electrons; $c)$ enlarged image of a phase containing iron and phosphorus in secondary electrons; $d$ ) distribution of a number of elements (indicated under each map) along the surface shown in Fig. 11, a, b 
Из карт распределения элементов (рис. 11, 2) видно, что церий в основном связан с фтором (светлая фаза на рис. 11, б), но также присутствует в областях с повышенным содержанием фосфора, которые, по-видимому, относятся к непрореагировавшему МК. Кремний образует отдельную фазу с фтором, соответствующую, судя по всему, кремнефториду аммония. Железо, фосфор и кислород в некоторых областях встречаются совместно, причем атомарное соотношение фосфора и кислорода приблизительно равно 2,5:9,3, что может соответствовать $\left[\mathrm{PO}_{4}\right]^{3-}$. Также в данных областях обнаруживаются примеси алюминия и кальция, содержание фтора варьируется, а содержание азота ниже предела обнаружения. Образование данного соединения объясняет характер зависимостей степеней выщелачивания железа и фосфора от температуры процесса (рис. 7).

По результатам исследования по гидрофторированию МК можно констатировать, что продукты фторирования в основном состоят из фторидов РЗЭ, фторидов или фтораммонийных соединений металлов и относительно небольшого количества непрореагировавшего МК. Железо представлено фразами гексафтоферрата аммония и фосфата железа. Фосфор образует растворимые гидрофторфосфаты аммония, малорастворимые фосфат железа и пирофосфат тория, и в небольшом количестве переходит в газообразную фазу, вероятно, в виде $\mathrm{POF}_{3}$.

\section{Заключение}

1. Определены основные физико-химические свойства монацитового концентрата. Содержание оксидов РЗЭ варьируется от 41,00 до 43,89 мac. $\%, \mathrm{P}_{2} \mathrm{O}_{5}-19,92-20,67$ мac. $\%, \mathrm{SiO}_{2}-$ $3,14-3,36$ мac. $\%, \mathrm{ThO}_{2}-5,88-6,11$ мac. $\%$, $\mathrm{U}_{3} \mathrm{O}_{8} 0,16-0,28$ мac. $\%$.

2. При изучении пространственного распределения элементов методом СЭМ неоднородность в распределении кальция, тория и кремния по шлифу зерна МК позволила предположить наличие в монаците вростков хаттонита и чералита. Присутствие хаттонита было также подтверждено методом рентгенофазового анализа, кроме того, обнаружена фаза $\mathrm{Nd}_{2} \mathrm{Si}_{2} \mathrm{O}_{7}$.

\section{СПИСОК ЛИТЕРАТУРЫ}

1. Modified acidic leaching for selective separation of thorium, phosphate and rare earth concentrates from Egyptian crude monazite / E.H. Borai, M.A. El-Ghany, I.M. Ahmed, M.M. Hamed et al. // International Journal of Mineral Processing. - 2016. V. 149. - P. 34-41. DOI: 10.1016/j.minpro.2016.02.003

2. Sadri F., Rashchi F., Amini A. Hydrometallurgical digestion and leaching of Iranian monazite concentrate containing rare earth elements Th, Ce, La and Nd // International Journal of Mineral Processing. - 2017. - V. 159. - P. 7-15. DOI: 10.1016/j.minpro.2016.12.003

3. Demol J., Ho E., Senanayake G. Sulfuric acid baking and leaching of rare earth elements, thorium and phosphate from a monazite concentrate: Effect of bake temperature from 200 to $800{ }^{\circ} \mathrm{C} / /$
3. Для эффективного удаления кремния с целью увеличения выхода РЗЭ во фториды, а также разложения трудновскрываемой кристаллической решетки самого монацита были проведены исследования по фторированию МК. В качестве реагента был выбран БФА как более безопасный с экологической точки зрения по сравнению с $\mathrm{HF}$ и $\mathrm{F}_{2}$, а также благодаря возможности его регенерации с возвратом в процесс.

4. На основании термогравиметрического анализа показано, что при взаимодействии МК с БФА в первую очередь в реакцию вступают примеси, и лишь потом компоненты монацита. Образующаяся при этом фосфорная кислота взаимодействует с БФА с образованием гидродифторфосфата аммония, который затем разрушается до гидромонофторфосфата аммония с выделением, повидимому, $\mathrm{POF}_{3}$. Это предположение подтверждено дальнейшими исследованиями: основная часть фосфора при фторировании остается в твердой фазе $(49,2-83,3 \%)$, в жидкую переходит $12,0-32,8 \%$, в газообразную - 11,2-28,1 \% . По результатам анализа продукта фторирования методами рентгенофазового анализа и СЭМ показано присутствие в твердой фазе пирофосфата тория и фосфата железа. Образование данных соединений позволяет предположить возможность их отделения от РЗЭ на стадии выщелачивания при дальнейшей кислотной переработке продуктов фторирования.

5. Экспериментально показано, что содержания в продуктах фторирования после выщелачивания водой кремния значительно снижается (до 0,17-0,51 мас. \% ) по сравнению с его содержанием в исходном концентрате. По составленному материальному балансу 10,4-38,4 \% кремния от его содержания в исходном концентрате переходит в газовую фазу в виде $\mathrm{SiF}_{4}$, $55,3-75,9 \%$ - в раствор выщелачивания в виде растворимого $\left(\mathrm{NH}_{4}\right)_{2} \mathrm{SiF}_{6}$.

6. На основании полученных результатов выбраны оптимальные условия для проведения процесса гидрофторирования МК БФА: температуpa $210{ }^{\circ} \mathrm{C}$; содержание БФА $80 \%$ от стехиометрии; продолжительность процесса 1,5 часа.

Hydrometallurgy. - 2018. - V. 179. - P. 253-267. DOI: 10.1016/j.hydromet.2018.06.002

4. Borai E.H., El Afifi E.M., El-Din A.S. Selective elimination of natural radionuclides during the processing of high grade monazite concentrates by caustic conversion method // Korean Journal of Chemical Engineering. - 2017. - V. 34. - № 4. - P. 1091-1099. DOI: $10.1007 / \mathrm{s} 11814-016-0350-9$

5. Alkali pug bake process for the decomposition of monazite concentrates / L. Berry, J. Galvin, V. Agarwal, M.S. Safarzadeh // Minerals Engineering. - 2017. - V. 109. - P. 32-41. DOI: 10.1016/j.mineng.2017.02.007

6. Brisson V.L., Zhuang W.Q., Alvarez-Cohen L. Bioleaching of rare earth elements from monazite sand // Biotechnology and bioengineering. - 2016. - V. 113. - № 2. - P. 339-348. DOI: $10.1002 /$ bit.25823 
7. Selective extraction of rare earth elements from complex monazite ores / L.A.V. Teixeira, R.G. Silva, D. Majuste, V. Ciminelli // Extraction 2018. Proc. of the First Global Conference on Extractive Metallurgy. - Canada: Springer, Cham, 2018. P. 2381-2390. DOI: 10.1007/978-3-319-95022-8_200

8. Технологические аспекты переработки редкометальных руд Чуктуконского месторождения / В.И. Кузьмин, Г.Л. Пашков, В.Н. Кузьмина, С.Н. Калякин // Химия в интересах устойчивого развития. - 2010. - Т. 18. - № 3. - С. 331-338.

9. The study of rare earth production based on processing of phosphorus-containing concentrates / A.S. Bujnovskij, V.I. Sachkov, P.B. Molokov, A.V. Anufrieva // Key Engineering Materials. - 2016. - V. 683. - P. 209-213. DOI: 10.4028/www.scientific.net/KEM.683.395

10. Выделение редкоземельных элементов, урана и тория из монацитового концентрата методом сверхкритической флюидной экстракции / М.Д. Самсонов, Т.И. Трофимов, Ю.М. Куляко, С.Е. Винокуров и др. // Радиохимия. - 2015. - Т. 57. - № 4. C. 291-294.

11. Репина С.А., Попова В.И., Баженова Л.Ф. Минералогия монацитовых концентратов ОГУ «Уралмонацит» // Уральский минералогический сборник. - 2008. - № 15. - С. 17-26.

12. Репина С.А. Распределение редкоземельных элементов в кристаллах монацита из концентратов ОГУ «Уралмонацит» // Уральский минералогический сборник. - 2009. -№ 16. C. 100-112.

13. Geochemistry of Monazite within Carbonatite Related REE Deposits / W. Chen, H. Honghui, T. Bai, S. Jiang, W. Chen et al. // Resources. - 2017. - V. 6. - № 4. - P. 51-65. DOI: 10.3390/resources6040051

14. Decomposition of diverse solid inorganic matrices with molten ammonium bifluoride salt for constituent elemental analysis / M.J. O'Hara, C.M. Kellogg, C.M. Parker, S.S. Morrison et al. // Chemical Geology. - 2017. - V. 466. - P. 341-351. DOI: 10.1016/j.chemgeo.2017.06.023
15. Influence of $\mathrm{NH}_{4} \mathrm{HF}_{2}$ activation on leaching of low-grade complex copper ore in $\mathrm{NH}_{3}-\mathrm{NH}_{4} \mathrm{Cl}$ solution / J. Han, W. Liu, K. Xue, W. Qin et al. // Separation and Purification Technology. 2017. - V. 181. - P. 29-36. DOI: 10.1016/j.seppur.2017.03.012

16. Ищенко А.А. Аналитическая химия и физико-химические методы анализа. - М.: ИЦ «Академия», 2010. - Т. 2. - 416 с.

17. Способ переработки монацитового концентрата: пат. Российская Федерация № 2549412 МПК С01F 17/00; заявл. 14.10.2013; опуб. 27.04.2015, Бюл. № $12 .-7$ с.

18. Исследование вскрытия монацита смесью серной кислоты и гидродифторида аммония / Д.В. Акимов, А.Н. Дьяченко, Н.Б. Егоров, А.Д. Киселёв, К.В. Обмуч // Фторидные технологии в атомной промышленности. Громовские Чтения. - Томск: ТПУ, 2014. - C. 41-42.

19. Influence of adding ammonium bifluoride when leaching monazite using sulphur acid / N. Egorov, N. Dyachenko, D. Akimov et al. // Procedia Chemistry. - 2014. - V. 10. - P. 168-172. DOI: 10.1016/j.proche.2014.10.029

20. Лапташ Н.М., Кайдалова Т.А. Твердофазное взаимодействие фторапатита с гидрофторидом аммония // Журнал неорганической химии. - 1996. - Т. 41. - № 4. - С. 557-559.

21. Крайденко Р.И. Фтороаммонийное разделение многокомпонентных силикатных систем на индивидуальные оксиды: автореф. дис. ... канд. хим. наук. - Томск, 2008. - 21 с.

22. Раков Э.Г., Мельниченко Е.И. Свойства и реакции фторидов аммония // Успехи химии. - 1984. - T. LIII. - № 9. C. $1463-1492$.

23. Горбенко О.М., Эпов Д.Г., Полищук С.А. Исследование взаимодействия гидрофторида аммония с пирротином и фторапатитом // Тезисы докладов IX Всесоюзного симпозиума по химии неорганических фторидов. - Череповец, 1990. - С. 110.

Поступила 14.11.2018 г.

\section{Информация об авторах}

Муслимова A.B., старший преподаватель кафедры химии и технологии материалов современной энергетики Северского технологического института - филиала Национального исследовательского ядерного университета «МИФИ».

Буйновский A.C., доктор технических наук, профессор кафедры химии и технологии материалов современной энергетики Северского технологического института - филиала Национального исследовательского ядерного университета «МИФИ» .

Молоков П.Б., кандидат технических наук, доцент кафедры химии и технологии материалов современной энергетики Северского технологического института - филиала Национального исследовательского ядерного университета «МИФИ» .

Софронов B.Л., доктор технических наук, профессор кафедры химии и технологии материалов современной энергетики Северского технологического института - филиала Национального исследовательского ядерного университета «МИФИ». 


\title{
INTERACTION OF MONAZITE AND AMMONIUM BIFLUORIDE
}

\author{
Alexandra V. Muslimova', \\ klameri7@gmail.com
}

\author{
Alexander S. Buinovskiy', \\ ASBujnovskij@mephi.ru \\ Petr B. Molokov ${ }^{1}$ \\ PBMolokov@mephi.ru \\ Vladimir L. Sofronov', \\ VLSofronov @mephi.ru \\ ' Seversk Technological Institute - branch of National Research Nuclear University «MEPhl», \\ 65, Kommunistichesky avenue, Seversk, 636036, Russia.
}

Up-to-date technologies providing scientific and technological progress are based on the unique properties of rare-earth metals and their compounds. In recent years, the attempts have been made to revive rare-earth metals production in Russia, mainly using the sources from which rare-earth elements can be extracted simultaneously (apatites, phosphorites and products of their processing). Another source of rare-earth elements, which is a ready concentrate, is monazite concentrate stored in the warehouse of the state government institution of the Sverdlovsk region «UralMonatsit» in Krasnoufimsk. The known industrial technologies of its processing (alkaline and sulfuric acid) have a number of drawbacks, in particular, the incompleteness of rare-earth elements extraction and the complexity of separating thorium from rare-earth elements. Therefore, there is the relevance of the work on improving the processing technologies of monazite raw materials with extraction of rare-earth elements concentrate and its refinement from impurities, including purification from thorium. To decompose the difficult-to-open crystalline lattice of monazite effectively, its fluorination with ammonium hydrofluoride as a relatively environmentally friendly and regenerable reagent is proposed.

The maim aim of the research is to study the process and determine the features of interaction of monazite concentrate with ammonium bifluoride to produce a product suitable for further sulfuric acid processing.

The object of the research is a sample of monazite concentrate in the storage of the SGI SR UralMonatsit.

Research methods. Atomic emission spectroscopy with inductively coupled plasma, X-ray fluorescence analysis, neutron activation analysis, X-ray phase analysis, scanning electron microscopy with microanalysis, method of combined thermogravimetric/differentialthermogravimetric/differential scanning calorimetric analysis.

Results. The paper considers the first stage of the proposed fluorammonium-sulfuric acid processing of monazite concentrates, i.e. the hydrofluorination stage. In the interaction of monazite concentrate with ammonium bifluoride, the impurities contained in the concentrate are the first to enter into a reaction with the formation of fluorides and fluoromammonium compounds; after that the rare-earth metals phosphates enter into reaction. The resulting phosphoric acid reacts with ammonium bifluoride to form ammonium hydrophosphates and a slight phosphorus emission into the gaseous phase. This is confirmed by the results of studies carried out in the temperature range of $170-250^{\circ} \mathrm{C}: 49,2-83,3 \%$ of phosphorus remains in the solid phase during fluorination, $12,0-32,8 \%$ of phosphorus changes into the liquid phase, $11,2-28,1 \%$ of phosphorus changes into gaseous phase. With a further increase in temperature up to $500{ }^{\circ} \mathrm{C}$, there are no signs of reaction proceeding on the obtained TGA and DSC curves. This allows us to say that complete distillation of phosphorus from the fluorination products in the studied temperature range is impossible. According to the material balance, $10,4-38,4 \%$ of silicon from its content in the initial concentrate transforms into the gas phase in the form of $\mathrm{SiF}_{4}, 55,3-75,9 \%-$ into the leaching solution in the form of soluble $\left(\mathrm{NH}_{4}\right)_{2} \mathrm{SiF}_{6}$, which can be decomposed to gaseous $\mathrm{SiF}_{4}$ with further acid processing. On the basis of the results obtained, optimal conditions for fluorination of the monazite concentrate with ammonium hydrofluoride are chosen: temperature is $210^{\circ} \mathrm{C}$; ammonium bifluoride content is $80 \%$ of stoichiometry; the duration of the process is 1,5 hours.

\section{Key words:}

Monazite, monazite concentrate, ammonium hydrogen difluoride, ammonium bifluoride, rare-earth elements, thorium, silicon, phosphorus.

\section{REFERENCES}

1. Borai E.H., El-Ghany M.A., Ahmed I.M., Hamed M.M. Modified acidic leaching for selective separation of thorium, phosphate and rare earth concentrates from Egyptian crude monazite. International Journal of Mineral Processing, 2016, vol. 149, pp. 34-41. DOI: $10.1016 /$ j.minpro.2016.02.003

2. Sadri F., Rashchi F., Amini A. Hydrometallurgical digestion and leaching of Iranian monazite concentrate containing rare earth elements Th, $\mathrm{Ce}, \mathrm{La}$ and Nd. International Journal of Mineral Processing, 2017, vol. 159 , pp. 7-15. DOI: $10.1016 /$ j.minpro.2016.12.003

3. Demol J., Ho E., Senanayake G. Sulfuric acid baking and leaching of rare earth elements, thorium and phosphate from a monazite concentrate: Effect of bake temperature from 200 to $800^{\circ} \mathrm{C}$. $\mathrm{Hy}$ drometallurgy, 2018, vol. 179, pp. 253-267. DOI: 10.1016/j.hydromet.2018.06.002

4. Borai E.H., El Afifi E.M., El-Din A.S. Selective elimination of natural radionuclides during the processing of high grade monazite concentrates by caustic conversion method. Korean Journal of Chemical Engineering, 2017, vol. 34, no. 4, pp. 1091-1099. DOI: $10.1007 / \mathrm{s} 11814-016-0350-9$

5. Berry L., Galvin J., Agarwal V., Safarzadeh M.S. Alkali pug bake process for the decomposition of monazite concentrates. Minerals Engineering, 2017, vol. 109, pp. 32-41. DOI: 10.1016/ j.mineng.2017.02.007

6. Brisson V.L., Zhuang W.Q., Alvarez-Cohen L. Bioleaching of rare earth elements from monazite sand. Biotechnology and bioengi- 
neering, 2016, vol. 113, no. 2, pp. 339-348. DOI: 10.1002/ bit. 25823

7. Teixeira L.A.V., Silva R.G., Majuste D., Ciminelli V. Selective extraction of rare earth elements from complex monazite ores. Extraction 2018. Proceedings of the First Global Conference on Extractive Metallurgy. Canada, Springer, Cham, pp. 2381-2390. DOI: 10.1007/978-3-319-95022-8_200

8. Kuzmin V.I., Pashkov G.L., Kuzmina V.N., Kalyakin S.N. Technological features of the rare-metal ores from the Chuktukon deposit. Chemistry for Sustainable Development, 2010, vol. 18, no. 3, pp. 331-338. In Rus.

9. Bujnovskij A.S., Sachkov V.I., Molokov P.B., Anufrieva A.V. The study of rare earth production based on processing of phosphorus-containing concentrates. Key Engineering Materials, 2016, vol. 683, pp. 209-213. D0I: 10.4028/www.scientific.net/KEM.683.395

10. Samsonov M.D., Trofimov T.I., Kulyako Y.M., Vinokurov S.E. Recovery of rare earth elements, uranium, and thorium from monazite concentrate by supercritical fluid extraction. Radiochemistry, 2015, vol. 57, no. 4, pp. 291-294. In Rus.

11. Repina S.A., Popova V.I., Bazhenova L.F. Mineralogy of the monazite concentrations from «UralMonazite». Ural Mineralogy Collected Papers, 2008, no. 15, pp. 17-26. In Rus.

12. Repina S.A. Distribution of REE in monazite crystals from concentrations of «UralMonazite». Ural Mineralogy Collected Papers, 2009, no. 16, pp. 100-112. In Rus.

13. Chen W., Honghui H., Bai T., Jiang, S. Chen W. Geochemistry of Monazite within Carbonatite Related REE Deposits. Resources, 2017, vol. 6, no. 4, pp. 51-65. DOI: 10.3390/resources6040051

14. O'Hara M.J., Kellogg C.M., Parker C.M., Morrison S.S. Decomposition of diverse solid inorganic matrices with molten ammonium bifluoride salt for constituent elemental analysis. Chemical Geology, 2017, vol. 466, pp. 341-351. D0I: 10.1016/j.chemgeo.2017.06.023

15. Han J., Liu W., Xue K., Qin W. Influence of $\mathrm{NH}_{4} \mathrm{HF}_{2}$ activation on leaching of low-grade complex copper ore in $\mathrm{NH}_{3}-\mathrm{NH}_{4} \mathrm{Cl}$ solution. Separation and Purification Technology, 2017, vol. 181, pp. 29-36. D0I: 10.1016/j.seppur.2017.03.012

16. Ishenko A.A. Analiticheskaya khimiya i fiziko-khimicheskie metody analiza [Analytical chemistry and physical and chemical laboratory test]. Moscow, Academiya Publ., 2010. Vol. 2, 416 p.
17. Akimov D.V., Diachenko A.N., Egorov N.B., Kiselev A.D., Larin V.K. Sposob pererabotki monatsitovogo kontsentrata [Method of processing monazite concentrate]. Patent RF, no. 2549412, 2015.

18. Akimov D.V., Diyachenko A.N., Egorov N.B., Kiselev A.D., Obmuch K.V. Issledovanie vskrytiya monatsita smesyu sernoy kisloty i gidrodiftorida ammoniya [Investigation of dissection of monazite with a mixture of sulfuric acid and ammonium hydrofluoride]. Materialy vserossiyskoy nauchno-prakticheskoy konferentsii. Ftoridnye tekhnologii $v$ atomnoy promyshlennosti [Fluoride technologies in the nuclear industry. Proc. of the All-Russia research to practice conference]. Tomsk, TPU Publ., 2014. pp. 41-42.

19. Egorov N., Dyachenko N., Akimov D. Influence of adding ammonium bifluoride when leaching monazite using sulphur acid. Procedia Chemistry, 2014, vol. 10, pp. 168-172. DOI: 10.1016/j.proche.2014.10.029

20. Laptash N.M., Kaidalova T.A. Solid-Phase Interaction of Fluorapatite with Ammonium Hydrogen Difluoride. Russian Journal of Inorganic Chemistry, 1996, vol. 41, no. 4, pp. 557-559. In Rus.

21. Kraydenko R.I. Ftoroammoniynoe razdelenie mnogokomponentnykh silikatnykh sistem na individualnye oksidy. Avtoreferat Diss. Kand. nauk [Separation of multicomponent silicate systems into individual oxides by fluorammonium method. Cand. Diss. Abstract]. Tomsk, 2008. $21 \mathrm{p}$.

22. Rakov E.G., Melnichenko E.I. The Properties and Reactions of Ammonium Fluorides. Russian Chemical Reviews, 1984, vol. 53, no. 9. pp. 1463-1492. In Rus.

23. Gorbenko 0.M., Epov D.G., Polishchuk S.A. Issledovanie vzaimodeystviya gidroftorida ammoniya s pirrotinom i ftorapatitom [Study of interaction of ammonium hydrofluoride with pyrrhotine and fluorapatite]. Materialy IX vsesoyuznogo simpoziuma po khimii neorganicheskikh ftoridov [Proc. of the IX All-Soviet Union Symposium on the inorganic fluoride chemistry]. Cherepovets, MHTI im. Mendeleeva Publ., 1990. pp. 110.

Received: 14 November 2018.

\section{Information about the authors}

Alexandra V. Muslimova, senior lecturer, Seversk Technological Institute - branch of National Research Nuclear University «MEPhI».

Alexander S. Buinovskiy, Dr. Sc., professor, Seversk Technological Institute - branch of National Research Nuclear University «MEPhI».

Petr B. Molokov, Cand. Sc., associate professor, Seversk Technological Institute - branch of National Research Nuclear University «MEPhI».

Vladimir L. Sofronov, Dr. Sc., professor, Seversk Technological Institute - branch of National Research Nuclear University «MEPhI». 